\title{
Floral Phenology and Pollination Ecology of Punica granatum L. in Kathmandu, Nepal
}

\author{
Subodh Adhikari ${ }^{1}$ and Mahesh Kumar Adhikari ${ }^{2}$ \\ ${ }^{1}$ Amrit Campus, Tribhuvan University, Kathmandu \\ ${ }^{2}$ Natural History Museum, Tribhuvan University, Kathmandu \\ e-mail:ssubory@yahoo.com
}

\begin{abstract}
The phenological and ecological study on Punica granatum L., a cultivated and wild species found in outer Himalayan ranges and warm inner valleys (alt. 700 - 2700m), was carried out during April and May of 2006 and 2007 in Kathmandu Valley. The study covered blooming time, size of flower, its correlation and interaction with the visitors and pollinators. The prime pollinator was Apis cerena along with A. mellifera. Normal range of the length of a full blooming flower (mature flower) was 4.1 to $4.7 \mathrm{~cm}$ (in bagged flower) and 3.8 to $4.9 \mathrm{~cm}$ (in open flower). The fruiting rate was higher in case of the open flowers than the bagged one. Visitor's/pollinator's flower visit rate (visits/time) was found higher (most effective) in morning with sunny weather (766 times out of 1365). Similarly, the least effective time was dawn and dusk with cloudy and rainy weather (2 times each out of 1365).
\end{abstract}

Key words: floral phenology, visitors/pollinators

\section{Introduction}

\section{Introduction to the species}

Punica granatum L. is a member of the family Punicaceae. It is a glabrous shrub or small tree of 5$10 \mathrm{~m}$ height. Branchlets are often spine-tipped, bark is smooth, dark grey, leaves are 2 - 8cm long, entire, lanceolate to broadly oblanceolate, opposite, shining, narrowed to a short petiole. Flowers on the tip of axillary shoots, with crinkle petals, blooms between late spring and early summer (May-June). Calyx 2 - 3 cm long, tubular with 5 - 7 triangular fleshy lobes. Petals 5 - 7, bright red, rarely white or yellowish (Partap 1997, Lama et al. 2001, Joshi \& Joshi 2001). Stamens numerous. Pollen grains $22.6 \pm 1.04 \mu \mathrm{m}$ long and 21.6 $\pm 1.9 \mu \mathrm{m}$ broad, yellow in colour, spherical in shape, and tri-colporate with a smooth exine. Fruits are round or ovoid, $5 \mathrm{~cm}$ in diameter, at first greenish then brownish, orange to scarlet, with a semi-woody pericarp, interior with separating membranous wall containing numerous seeds. Seeds have edible fleshy red, pink or whitish external layer (Partap 1997, WHO 1999, Bista et al. 2001, Lama et al. 2001, Joshi \& Joshi 2001).

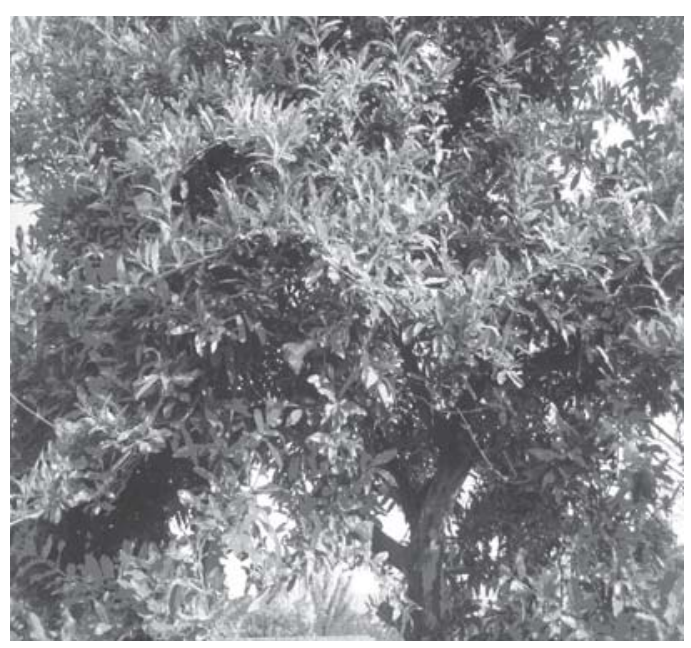

Fig.1.A Punica granatum tree on its natural habitat

It grows wild on both shores of the Mediterranean belt, Arabia, Persia, Bengal, China, Japan, Central and Western Asia. There are pocket areas in the Hind Kush Himalayan $(\mathrm{HKH})$ region, where its pure wild forests exist in hot, dry valley areas. This species has been 
introduced into the East and West Indies. It is cultivated in all countries, where the climate is warm including Asia especially the eastern Himalayas and southern Europe(Kochhar 1998, http://www.herbdatanz.com/ pomeganate.htm).

In Nepal, a single species of Punica (Punica granatum L.) has been reported (Bista et al. 2001). In Nepal, both cultivated and wild forms grow in open and dry slopes of warm valleys and outer hills ranging from 700 to 2700m (Lama et al. 2001, Joshi \& Joshi 2001, Chaudhary 1998, DMP 1970). It is locally known as Anar and Darim.

\section{Phytochemicals and Uses}

The root and bark contain tannin (20-22\%) and alkaloids (0.5-1\%). The seeds contain steroidal oestrogen. The fruit pulp contains protein, carbohydrate, fat, fibre, minerals, oxalic acid and vitamins A, B and C. In early times Greeks and Romans used Punica for tanning leathers, which is obtained from root, bark, stem, leaves and fruit rind (Kochhar 1998, Joshi \& Joshi 2001). Root, stem bark, rind, Fruit juice, powder of whole fruit and seeds are used as medicine. It is very useful in tapeworm infections, diarrhoea and dysentery. Besides, it is used in leucorrhoea, as a gargle agent in sore of throat, cardiac disorders, leprosy and stomachic problems. The juice is used as tonic, refrigerant, anti-inflammatory and antiprostrate cancer (DMP 1970, WHO 1999, Lama et al. 2001, Joshi \& Joshi 2001, http://www.herbdatanz.com/ pomeganate.htm). The juice is highly nutritious for the patients so it is an expensive fruit in Nepal.

The present article throws light on floral phenology and ecology influencing visitors and pollinators, which has not been previously studied.

Floral phenology and Pollination ecology

The time and duration of budding, flowering, wilting and fruiting of any plant is essential aspect in the study of pollination as they provide vivid knowledge on the activity of the visitor (Kearns \& Inouye 1993). The role of corolla, which is mainly related to attract pollinators, depends upon its structure, color and appearance. In some flowers a spot of different color on the corolla directs the insect to the interior of the flower, guiding the pollinators toward their destination. For instance, Pedicularis dendrothauma has a corolla with a pinkish spot (Macior 1990, Adhikari 2003).
The length of stamen and gynoecium also play an active role in pollen transfer. Besides these, flowers have other floral cues like nectar, sugar, odour and oil to attract the insects, which help in pollination. In some species, insect visit is directly related with plant height (Kearns \& Inouye 1993) and also varies with size of the inflorescence (Thomson 1988). So the floral phenological study is an integral part of the pollination studies.

Both plants and pollinators are affected by environmental variables (Kearns \& Inouye 1993). Flower development and opening, nectar secretion, anther dehiscence and seed development are all dependent on ambient temperature. Similarly, air temperature affects the activity of flower-visiting insects. Bees, the most important pollinators, can't go outside their hive in cold weather (Adhikari 2003, Adhikari 2004). Some evolutionary co-adaptation can be seen between many flowers and their pollinators (Macior 1990 \& 1984).

\section{Conservation and Pollination}

Pollination systems are under increasing threat mainly from anthropogenic sources, including fragmentation and alteration of habitat, changes in land use pattern, modern agri practices, move towards monocultures, use of chemicals such as pesticides, and invasions of alien species (Kearns et al. 1998, Adhikari 2004). In many places of the world, the 'pollination crisis' is evident in declines of honeybees and native bees and in damage to webs of plant-pollinator interactions. The inevitable and obligate role of pollination makes it clear that the conservation of pollination systems is an important priority for all (Kearns et al. 1998, Adhikari 2003). The declining apple production in the Hind Kush-Himalayas (HKH) region is due to the loss of local /wild pollinators and consequently due to the inadequate crop pollination (Partap \& Partap 2001, Ahmad et al. 2002, Adhikari 2003).

\section{Historical review of pollination study}

The science of anthecology began around 200 years ago. Since then, Kolreuter (1761), Muller (1881), Knuth (1898-1905), Robertson (1929), Miyamoto (1962), and others have accumulated prodigious records of pollinator diversity on flowers. Less than 50 years, however, have elapsed since Kugler and other pollination ecologists, following studies of insect 
behavior by Frisch and his colleagues, began critical studies on pollination dynamics (Macior 1971).

The studies on the pollination ecology started with the works on Pedicularis in Europe (Knuth 1898-1905), North America (Macior 1982, 1983, 1986a, 1986b, 1986c) and Japan (Macior 1988). They have demonstrated close correspondence of floral function and pollinator behavior. Recently, such studies have been carried out in Asia (Macior 1990). For example, Deyrup \& Menges (1997) studied on Dicerandra frutescens (Lamiaceae), Proctor, Yeo \& Lack (1996) studied on insect visitors, Adams (1982) studied on Pedicularis pollination, Boyle \& Menges (2001) studied on Hypericum cumulicola (Hypericaceae), and Paulus \& Gack (1998) studied on the pollination of Ophrys (Orchidaceae). Kearns \& Inouye (1993) published a book on 'Techniques for Pollination Biologists". O’Neill (1997) and Dafni (1984), has significant contribution on the field. Similarly Jones \& Little (1983) also published book named "Hand book of experimental pollination biology”(Adhikari 2003).

The pollination ecology of Pedicularis species in Asia include the contributions of Macior (1990) in Kasmir Himalaya, Macior (1995), and Macior \& Sood (1991) in Himachal Pradesh (India), Macior \& Tang (1997) in China, Tang et al. (1998), and Macior et al. (2001) in China (Adhikari 2003).

Since then till now, many authors have thrown light on pollination biology. However, Nepal has remained virgin in this area except a few of the works done by the author.

\section{Study Area}

Study area included different places of Kathmandu valley, Central Nepal.The Kathmandu valley lies

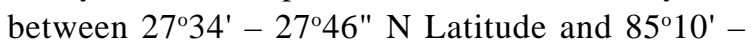
$85^{\circ} 52^{\prime}$ E longitude with its unique physiography (altitude ranging between 1350 - $2765 \mathrm{msl}$ ) covering an area of $650 \mathrm{sq} \mathrm{km}$. The valley is drained by the rivers Bagmati and Bishnumati and their tributaries The cool subtropical to temperate climate and surrounding ranges (Shivapuri 1910m, Nagarjoon 2500m, Phulchwoki -2765m, and Chandragiri$2220 \mathrm{~m}$ ), which abound with scenic natural beauty (ever green oak laurel forest, which contain different religious areas and picnic spots of botanical interest (Adhikari 1988). Punica granatum has been cultivated in many places inside and outside valley.

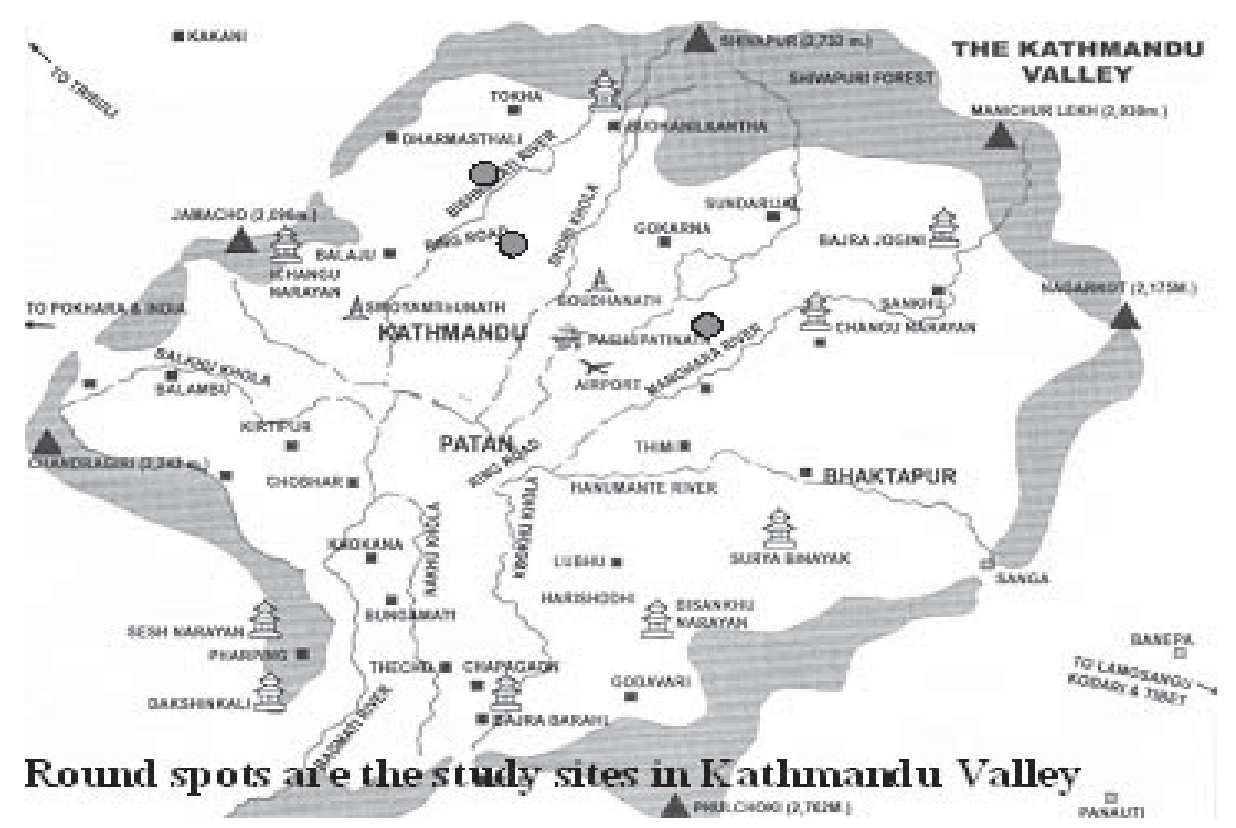

Fig.2. Study area 


\section{Methodology}

The flowering phenological record of Punica along with visit of insects was studied throughout the study period. The photography was also done.

\section{Floral phenology}

For the study of floral phenology, flowers were classified into different developmental classes/ conditions viz.

1 = Tight, unopened bud,

2 = developing bud/opening bud,

3 = open flower,

$4=$ mature flower,

$5=$ flower (corolla) wilting,

6 = corolla fallen off, fruit developing,

7 = Shade off / died out.

All together 20 days were spent for the study of flower development. Flower conditions were recorded in every five days. The measurement of each flower size/ length of corolla tube was taken at a five-day interval, for a total of five times. In addition, flowers were sectioned in order to observe the construction, arrangement and origin of all parts. A time table of morning, day and evening including dawn and dusk was prepared to watch the visit of pollinators in different flowers.

\section{Pollination ecology}

For the study of pollination ecology of Punica granatum, observation of pollinators' activities along with the collection and preservation of pollinators were done in April - May (the main blooming period) of 2006 and 2007. Altogether 77 hours of patient watching was carried out. While watching the visitors or pollinators, the insects' behavior on the flowers, number and species of visitors, their frequency of visit during different day times and weather conditions, date, no. of flowers on plant, whether the flower was shaded or sunlit during the observation as well as their visiting period were observed and recorded. Weather conditions were also recorded at regular time intervals. Visitors / pollinators were collected from the Punica flowers. The insect visitors were trapped and preserved for identification. Extensive non-timed flower observations for their development and visitors were made over 3 yrs (2005, 2006 \& 2007)

\section{Bagging Studies}

Some 15 healthy and unopened flowers (buds) were bagged in order to exclude the visitors/pollinators. The conditions of all buds and flowers were studied on the same day or interval as that of the flowers with no bagging (5 times in each five days of interval).

\section{Results and discussion}

Main blooming period of P. granatum flower was found 20 days ie. a bud of $P$. granatum normally takes 20 days for its complete maturation (Table $1 \& 2$ ). A young bud (condition - 1) measures up to $0.9 \mathrm{~cm}$ (in bagged condition) and up to $1 \mathrm{~cm}$ (in open condition), which is not a significant different. The bagged flowers were seen to mature first than the open flowers (Table 1 $\& 2)$. It may be due to certain increase in temperature in the bagged flowers as compared to the open flowers.

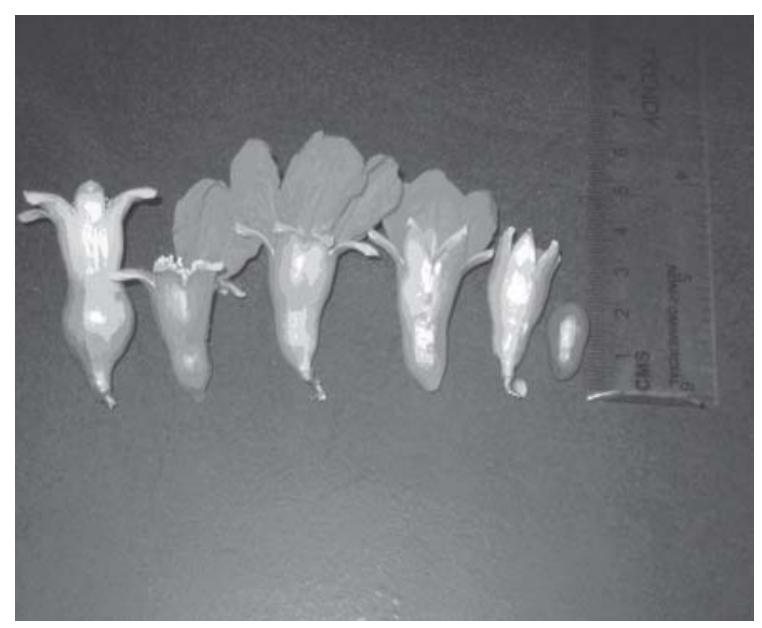

Fig.3. Punica flowers at different developmental conditions

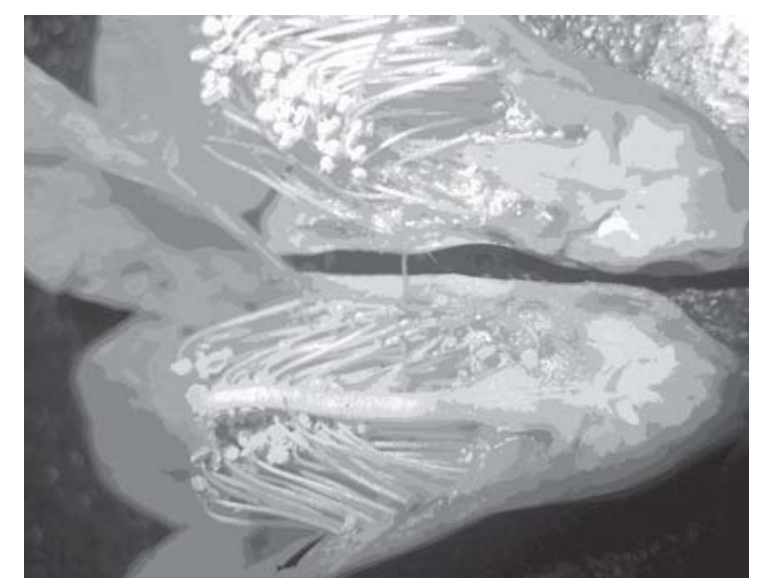

Fig. 4. Internal structure of Punica flower 
The normal range of the length of a full blooming flower (mature flower) was found to be 4.1 to $4.7 \mathrm{~cm}$ in bagged flower, while 3.8 to $4.9 \mathrm{~cm}$ in open flower (Table $1 \& 2$ ). This small difference in length may not be due to the bagging of flower. Fruiting is found higher in open flower (12/15) than in bagged flower (8/15). Fruiting in bagged flower may be either due to some error while bagging the flowers or due to some other pollinators present internally within the flowers.

Table 1. Floral phenological changes (in bagged flower)

\begin{tabular}{|c|c|c|c|c|c|c|c|c|c|c|}
\hline \multirow[t]{3}{*}{ Fl. no. } & \multirow{2}{*}{\multicolumn{2}{|c|}{$\begin{array}{l}\text { Time-6.15 AM } \\
\text { Date-20 - 4- } 2005\end{array}$}} & \multirow{2}{*}{\multicolumn{2}{|c|}{\begin{tabular}{|c|}
6.15 AM \\
$25-04-2005$ \\
\end{tabular}}} & \multirow{2}{*}{\multicolumn{2}{|c|}{$\begin{array}{l}\text { 6.15 AM } \\
30-04-2005\end{array}$}} & \multirow{2}{*}{\multicolumn{2}{|c|}{$\begin{array}{l}\text { 6.15 AM } \\
05-05-2005\end{array}$}} & \multirow{2}{*}{\multicolumn{2}{|c|}{$\begin{array}{l}6.15 \text { AM } \\
10-05-2005\end{array}$}} \\
\hline & & & & & & & & & & \\
\hline & \begin{tabular}{|l|} 
Flower \\
size $(\mathrm{cm})$
\end{tabular} & $\begin{array}{l}\text { Flower } \\
\text { condition }\end{array}$ & $\begin{array}{l}\text { Flower } \\
\text { size }(\mathrm{cm})\end{array}$ & \begin{tabular}{|l|} 
Flower \\
condition
\end{tabular} & \begin{tabular}{|l|} 
Flower \\
size $(\mathrm{cm})$
\end{tabular} & $\begin{array}{l}\text { Flower } \\
\text { condition }\end{array}$ & \begin{tabular}{|l|} 
Flower \\
size $(\mathrm{cm})$
\end{tabular} & \begin{tabular}{|l} 
Flower \\
condition
\end{tabular} & $\begin{array}{l}\text { Flower } \\
\operatorname{size}(\mathrm{cm})\end{array}$ & $\begin{array}{l}\text { Flower } \\
\text { condition }\end{array}$ \\
\hline 1 & 1.8 & 2 & 2.3 & 3 & 4.2 & 4 & - & 7 & - & 7 \\
\hline 2 & 2.2 & 2 & 2.9 & 3 & 4.3 & 4 & - & 7 & - & 7 \\
\hline 3 & 2.8 & 2 & 4.0 & 3 & - & 7 & - & 7 & - & 7 \\
\hline 4 & 1.5 & 2 & 1.6 & 2 & 3.2 & 3 & - & 7 & - & 7 \\
\hline 5 & 2.7 & 2 & 3.2 & 3 & 4.1 & 4 & - & 7 & - & 7 \\
\hline 6 & 1.5 & 2 & 1.7 & 2 & 2.4 & 2 & 3.8 & 3 & - & 7 \\
\hline 7 & 2.6 & 2 & 2.8 & 2 & 3.7 & 3 & - & 7 & - & 7 \\
\hline 8 & 1.5 & 2 & 1.9 & 2 & 3.4 & 3 & 4.7 & 4 & - & 7 \\
\hline 9 & 2.2 & 2 & 3.2 & 3 & 4.4 & 4 & - & 7 & - & 7 \\
\hline 10 & 3.0 & 2 & 4.3 & 3 & - & 7 & - & 7 & - & 7 \\
\hline 11 & 2.4 & 2 & - & 7 & - & 7 & - & 7 & - & 7 \\
\hline 12 & 0.7 & 1 & 0.9 & 1 & 1.7 & 2 & - & 7 & - & 7 \\
\hline 13 & 0.4 & 1 & 0.7 & 1 & 1.2 & 2 & 3.0 & 3 & - & 7 \\
\hline 14 & 0.9 & 1 & 1.9 & 2 & 3.4 & 3 & - & 7 & - & 7 \\
\hline 15 & 0.5 & 1 & 0.5 & 1 & 0.9 & 1 & 1.3 & 2 & - & 7 \\
\hline
\end{tabular}

Note: - 1=Tight, unopened bud, 2=developing bud/opening bud, 3= open flower, 4=mature flowers, 5=flower (corolla) wilting, $6=$ corolla fallen off, fruit developing, $7=$ Shade off/died out

Table 2. Floral phenological changes (in open/unbagged flower)

\begin{tabular}{|c|c|c|c|c|c|c|c|c|c|c|}
\hline \multirow[t]{3}{*}{ Fl. no. } & \multicolumn{2}{|c|}{ Time-7.15 AM } & \multicolumn{2}{|c|}{$7.15 \mathrm{AM}$} & \multicolumn{2}{|c|}{$7.15 \mathrm{AM}$} & \multicolumn{2}{|c|}{ 7.15 AM } & \multicolumn{2}{|c|}{ 7.15 AM } \\
\hline & \multicolumn{2}{|c|}{ Date-20 - 4- 2005} & \multicolumn{2}{|c|}{$25-04-2005$} & \multicolumn{2}{|c|}{$30-04-2005$} & \multicolumn{2}{|c|}{$05-05-2005$} & \multicolumn{2}{|c|}{$10-05-2005$} \\
\hline & $\begin{array}{l}\text { Flower } \\
\text { size }(\mathrm{cm})\end{array}$ & $\begin{array}{l}\text { Flower } \\
\text { condition }\end{array}$ & $\begin{array}{l}\text { Flower } \\
\text { size }(\mathrm{cm})\end{array}$ & $\begin{array}{l}\text { Flower } \\
\text { condition }\end{array}$ & $\begin{array}{l}\text { Flower } \\
\text { size }(\mathbf{c m})\end{array}$ & $\begin{array}{l}\text { Flower } \\
\text { condition }\end{array}$ & $\begin{array}{l}\text { Flower } \\
\text { size }(\mathrm{cm})\end{array}$ & $\begin{array}{l}\text { Flower } \\
\text { condition }\end{array}$ & $\begin{array}{l}\text { Flower } \\
\text { size }(\mathbf{c m})\end{array}$ & $\begin{array}{l}\text { Flower } \\
\text { condition }\end{array}$ \\
\hline 1 & 2.1 & 2 & 2.9 & 3 & 4.3 & 4 & - & 6 & - & 6 \\
\hline 2 & 2.2 & 2 & 2.9 & 3 & 4.6 & 4 & - & 6 & - & 6 \\
\hline 3 & 1.9 & 2 & 2.3 & 2 & 3.9 & 4 & - & 5 & - & 7 \\
\hline 4 & 1.0 & 1 & 1.7 & 2 & 3.2 & 3 & 4.3 & 4 & - & 6 \\
\hline 5 & 1.8 & 2 & 2.2 & 2 & 3.4 & 3 & 4.9 & 4 & - & 5 \\
\hline 6 & 0.2 & 1 & 0.9 & 1 & 1.4 & 2 & 2.7 & 3 & 3.1 & 4 \\
\hline 7 & 0.7 & 1 & 1.7 & 2 & 2.8 & 3 & 4.2 & 4 & - & 7 \\
\hline 8 & 2.2 & 2 & 3.1 & 3 & 4.7 & 4 & - & 7 & - & 7 \\
\hline 9 & 0.4 & 1 & 0.7 & 1 & 1.0 & 1 & 1.9 & 2 & 2.4 & 3 \\
\hline 10 & 2.0 & 2 & 3.4 & 3 & 4.7 & 4 & - & 5 & - & 6 \\
\hline 11 & 0.4 & 1 & 0.6 & 1 & 0.9 & 1 & 1.3 & 2 & 2.5 & 3 \\
\hline 12 & 2.2 & 2 & 3.9 & 3 & 4.4 & 7 & - & 7 & - & 7 \\
\hline 13 & 1.7 & 2 & 1.8 & 2 & 2.2 & 2 & 3.4 & 3 & 4.0 & 4 \\
\hline 14 & 1.9 & 2 & 2.5 & 2 & 3.8 & 4 & - & 6 & - & 7 \\
\hline 15 & 2.5 & 2 & 3.8 & 2 & 4.9 & 3 & 6.5 & 4 & - & 6 \\
\hline
\end{tabular}

The result received after watching the pollinators or visitors in selected flowers are tabulated below. A great attempt was made to watch all flowers from dawn to dusk and from rainy to sunny days. 
Nepal Journal of Science and Technology 11 (2010) 115-124

Table 3. Hours spent on different days for pollination studies and the visitors' frequency of visit

\begin{tabular}{|c|c|c|c|c|c|}
\hline Time of day/periods & \begin{tabular}{|l} 
Hours \\
spent for \\
study
\end{tabular} & $\begin{array}{l}\text { No. of } \\
\text { visitors/ } \\
\text { pollinators }\end{array}$ & \begin{tabular}{|l} 
Relative \\
percentage \\
of hours \\
spent
\end{tabular} & $\begin{array}{l}\text { Average } \\
\text { Visitor } \\
\text { /hr }\end{array}$ & Date \\
\hline Before or around Dawn (5.30-6.00) & 3 & 16 & 3.89 & 5.33 & $\begin{array}{l}20^{\text {th }}, 25^{\text {th }}, \& 28^{\text {th }} \text { of April and } 4^{\text {th }}, \\
6^{\text {th }} \& 9^{\text {th }} \text { of May } 2007\end{array}$ \\
\hline Morning (6.00-12 AM) & 36 & 980 & 46.75 & 27.22 & $\begin{array}{l}21^{\text {st }}, 25^{\text {th }}, 30 \text {, th of April and } 4^{\text {th }} \\
7^{\text {th }} \& 10^{\text {th }} \text { of May } 2007\end{array}$ \\
\hline Afternoon (12-3РM) & 18 & 196 & 23.38 & 10.88 & $\begin{array}{l}20^{\text {th }}, \quad 25^{\text {th }} \& 29^{\text {th }} \text { of April } \& 2^{\text {nd }}, 5^{\text {th }} \& \\
10^{\text {th }} \text { of May } 2007\end{array}$ \\
\hline Late noon /early evening (3-6.30) & 14 & 148 & 18.18 & 10.57 & $\begin{array}{l}24^{\text {th }}, 26^{\text {th }} \& 30^{\text {th }} \text { of April and } 8^{\text {th }} \\
\text { of May } 2007\end{array}$ \\
\hline Evening/Dusk (6.30-7.30) & 6 & 25 & 7.79 & 4.16 & $\begin{array}{l}20^{\text {th }} \& 25^{\text {th }} \text { of April and } 1^{\text {st }}, 4^{\text {th }}, 5^{\text {th }} \\
\text { and } 9^{\text {th }} \text { of May } 2007\end{array}$ \\
\hline Total & 77 hrs & 1365 & 100 & - & - \\
\hline
\end{tabular}

(Note-The term 'visitors' includes both the 'pollinators' and 'visitors'. Time spent by visitors on Punica flowers was generally 10 seconds to 5 minutes)

Table 4. Hours spent on different weather conditions for pollination studies and the visitors' frequency of visit

\begin{tabular}{|c|c|c|c|c|c|}
\hline $\begin{array}{l}\text { Weather } \\
\text { condition }\end{array}$ & $\begin{array}{l}\text { Hours } \\
\text { spent for } \\
\text { study }\end{array}$ & $\begin{array}{l}\text { No. of visitors/ } \\
\text { pollinators }\end{array}$ & $\begin{array}{l}\text { Relative } \\
\text { percentage } \\
\text { of hours } \\
\text { spent }\end{array}$ & $\begin{array}{l}\text { Average } \\
\text { Visitor/hr }\end{array}$ & Remarks \\
\hline $\begin{array}{l}\text { Clear, no sun, } \\
\text { no rain, no cloud/fog }\end{array}$ & 8 & 115 & 10.39 & 14.37 & \multirow{5}{*}{$\begin{array}{c}\text { Among 1365, } \\
1008 \text { are A. cerana, } \\
278=\text { A. mellifera, } \\
\text { 40=Bombus sp., } \\
\text { 10=Helina sp., } \\
\text { 7= Meliscaeva sp., } \\
\text { 6 = Vespula sp., } \\
\text { 7= Formica sp., } \\
\text { 5 = Fannia sp., \& } \\
\text { Unidentified sp=4, }\end{array}$} \\
\hline Clear-sun & 48 & 943 & 62.33 & 19.65 & \\
\hline Partly cloudy-sun & 16 & 286 & 20.78 & 17.87 & \\
\hline Cloudy/ Foggy -rain & 5 & 21 & 6.49 & 4.2 & \\
\hline Total & $77 \mathrm{hrs}$ & 1365 & 100 & - & \\
\hline
\end{tabular}

(Note: The term 'visitors'includes both the 'pollinators' and 'visitors'. Time spent by visitors on Punica flowers was generally 10 seconds to 5 minutes)

Table 5. List of Visitors/ Pollinators and their frequency of visit to Punica flowers

\begin{tabular}{c|l|c|c|l}
\hline S N. & \multicolumn{1}{|c|}{ Visitors/Pollinators } & $\begin{array}{l}\text { No. of visits } \\
\text { per watch hour }\end{array}$ & $\begin{array}{l}\text { Relative \% of } \\
\text { all visits }\end{array}$ & \multicolumn{1}{|c}{ Type of Interaction } \\
\hline 1 & $\begin{array}{l}\text { Apis cerena (fam. Apidae : Honey Bee) } \\
\text { Indigenous bee of Nepal }\end{array}$ & 13.09 & 73.85 & Primary Pollinator \\
2 & Apis mellifera (fam. Apidae : Honey Bee) & 3.61 & 20.37 & Major Pollinator \\
3 & Helina sp., (fam.-Muscidae:Dark fly) & 0.13 & 0.73 & Possible Pollen robber \\
4 & Meliscaeva sp.,(fam. - Syrphidae:Hover fly) & 0.09 & 0.51 & Pollen/ nectar robber \\
5 & Bombus spp (Apidae:Bumblebee) & 0.52 & 2.93 & Possible pollinator \\
6 & Fannia sp.,(fam.-Fanniidae:Small Dark grey fly) & 0.06 & 0.37 & Nectar and/or pollen \\
7 & Unidentified sp.,(fam.-Sepsidae: Small ant like fly) & 0.05 & 0.29 & robber \\
8 & Formica sp.( fam-Formicidae: Ant) & 0.09 & 0.51 & Causal visitor \\
9 & Vespula sp.(Vespidae:Wasp) & 0.08 & 0.44 & Bee killer/eater \\
\hline
\end{tabular}


The present studies have proved that the visit rate of pollinators is higher in the sunny period (19.65 visits per hour) or on the flowers which are exposed to sun rather than in shade (Table -4). The visit rate (visit/hr) were found to be increased with increase in flower

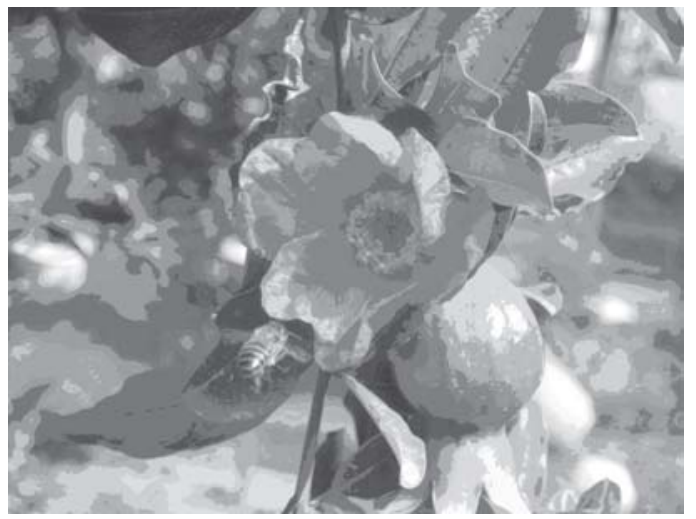

Fig.5. Apis cerena moving towards Punica flower

Cloudy and or foggy rain period has least number of visit rates (4.2/hr). However, visit rate is more in partly cloudy - sun (17.87/hr) and in clear weather condition $(14.37 / \mathrm{hr})$. The microclimates have an important effect even in the shade (Adhikari 2001, Kearns \& Inouye 1993, Deyrup \& Menges 1997). In the morning time (27.22/hr) with sunny days (19.67 visits per hour) are the most preferred time and weather $(56.11 \%$ of total visits) $=$ for the pollinators (table-3, 4 \& 6). Even the sunlit flowers were more visited by visitors than the shaded flowers. The duration of the longest pollinator visit decreases as the morning progresses. It is probably due to the depletion of pollen supplies (Boyle \& Menges 2001) and foraging become less profitable. Also in later days the visit rates were quite low. The dawn (5.33/hr) and dusk (4.16/hr) with cloudy- foggy density (in flower $/ \mathrm{m}^{2}$ ) indicating the positively densitydependent visit rate to different flowers. Similar observations were found in Dicerandra frutescens by Deyrup \& Menges (1997) and in Hypericum cumulicola by Boyle \& Menges (2001).



Fig.6. Apis cerena collecting pollen from Punica flower

rain (1.5\% each of total visits) are the least preferred time for the pollinators (table -3, 4 \&6). The dawn and Dusk with sun $(0.15 \%$ and $0.29 \%$ of total visits respectively) have shown a very low visit rate even in a favorable weather condition (sunny weather)(table6 ). It is probably due to a very limited sunny time in the dawn (normally before sun rise) and dusk (normally after sun set) periods. Although some flower visitors (birds, mammals, and some insects) are homoeothermic or capable of endothermic temperature regulation, others (e.g. many Diptera, solitary bees) are dependent on solar radiation to achieve the body temperature required for flight(Adhikari 2003), which is strongly supported by this study as bees are more active during the sunny periods.

Table 6. A two way contingency table for the visitors' activities at different weather conditions and time periods

\begin{tabular}{l|c|c|c|c|c}
\hline \multirow{2}{*}{ Time } & \multicolumn{5}{c}{ Weather conditions } \\
\cline { 2 - 6 } & $\begin{array}{l}\text { Clear, no sun, } \\
\text { no rain, no } \\
\text { cloud/fog } \\
\mathbf{( 8 ~ h r s )}\end{array}$ & $\begin{array}{l}\text { Clear-sun } \\
\mathbf{( 4 8} \mathbf{~ h r s )}\end{array}$ & $\begin{array}{l}\text { Partly cloudy } \\
\text {-sun (16 hrs) }\end{array}$ & $\begin{array}{l}\text { Cloudy/ } \\
\text { Foggy -rain } \\
\text { (5 hrs) }\end{array}$ & $\begin{array}{l}\text { Total no. of } \\
\text { visitors } \\
\mathbf{7 7 7} \text { hrs) }\end{array}$ \\
\hline Before or around Dawn (5.30-6.00) (3hrs) & 7 & 2 & 5 & 2 & $\mathbf{1 6}$ \\
Morning (6.00-12 AM) (36 hrs) & 64 & $\mathbf{7 6 6}$ & 142 & 8 & $\mathbf{9 8 0}$ \\
Afternoon (12-3PM) (18hrs) & 27 & 84 & 81 & 4 & $\mathbf{1 9 6}$ \\
Late noon /early evening (3-6.30) 14 (hrs) & 10 & 87 & 46 & 5 & $\mathbf{1 4 8}$ \\
Evening/Dusk (6.30-7.30) 6 (hrs) & 7 & 4 & 12 & 2 & $\mathbf{2 5}$ \\
Total no of visitors (77 hrs) & $\mathbf{1 1 5}$ & $\mathbf{9 4 3}$ & $\mathbf{2 8 6}$ & $\mathbf{2 1}$ & $\mathbf{1 3 6 5}$ \\
\hline
\end{tabular}


Nepal Journal of Science and Technology 11 (2010) 115-124

P. granatum is adapted for bee pollination rather than fly pollination. Apis cerena, which made 13.09 visits per hour, is the main/prime pollinator (includes 73.85\% of total visits) of Punica (Table-5). Assuming $12 \mathrm{hr}$ of visitation, each flower would be visited by about 157 Apis cerena, so pollinator limitation for seed production in $P$. granatum is unlikely. A. mellifera is also a major pollinator of Punica (20.37\%). The lower value of $A$. mellifera is may be due to the less number of $A$. mellifera in the vicinity of study area. The bumble bees (Bombus sp.) are the other important pollinators or may be the pollen robbers having $2.93 \%$ of all visits (table-5). Some other insects (having less than $3 \%$ of all visits and having less than 0.1 visits per hour) like Helina sp., Meliscaeva sp., Fannia sp., Formica sp. and Vespula sp. have also been reported as a visitor of the Punica flower (table-5). However they are not the true pollinators and probably most of them are pollen/nectar robbers. According to Partap (1997), in addition to the aforementioned insects, $P$. granatum is also visited by insects like butterflies, moths, beetles and hornets. However, they were not reported during this study.

Though, it is a good source of both pollen and nectar for the bees and insects, $P$. granatum is mainly visited for pollen .Pollen plants like $P$. granatum are important in beekeeping, especially at the time of colony buildup when bees need large amounts of protein for brood rearing. Pollen is the sole source of proteins, lipids, minerals, and vitamins needed to feed the brood and immature adult bees.

A more detailed study is needed using the latest technologies and methods for the further exploration especially regarding the co-evolution of Punica granatum with its prime pollinators.

\section{Acknowledgements}

The first author is thankful to Mr. Narayan Gautam, Mr. Vinayak Dhital and Mr. Arun Dhital for providing their gardens to execute this study.

\section{References}

Adhikari, M. K. 1988. New records of fleshy fungi from the Kathmandu valley. In: Cryptogams of the Himalayas. (Eds. M. Watanabe \& S. B. Malla). National Science Museum, Tsukuba, Japan. 1:133 139.
Adhikari, S. 2003. Floral Phenology and Pollination Ecology of Pedicularis dendrothauma R. R. Mill and D J Allard in Sikles (ACAP) Kaski, Nepal. M.Sc. Dissertation. Central Department of Botany, Tribhuvan University Kathmandu, Nepal.

Adhikari, S. and M.K.Adhikari. 2004. Bumblebees and their Relationship with Flower Morphology of Pedicularis species in Nepal. In: Proceedings of IV National Conference on Science and Technology, Kathmandu. Nepal Academy of Science and Technology, Pp. 997-1004.

Ahmad, F., U. Partap, S.R. Joshi, and M.B. Gurung. 2002. Why the Hindu Kush Himalayan (HKH) Region Needs the Native Hive Honeybee Apis cerana. Briefing paper, ICIMOD, Kathmandu, Nepal.

Bista, M.S., M.K. Adhikari and K.R. Rajbhandari. 2001. Flowering Plants of Nepal (Phanerogams).Bulletin of Plant Resources. (No.18), Department of Plant Resources, National Herbarium and Plant Lab, Lalitpur, Nepal. 399 pp.

Boyle, O.D. and E.S. Menges. 2001. Pollinator Visitation to Hypericum cumulicola (Hypericaceae), a Rare Florida Scrub Endemic. Florida Scientist. 64(2): 107-117.

Chaudhary, R.P.1998. Biodiversity in Nepal Status and Conservation. Know Nepal series No. 17, S. Devi, Saharanpur, India. $324 \mathrm{pp}$.

Dafni, A. 1984. Mimicry and Deception in Pollination. Annual Reviews, Ecol. Syst. 15:259-278.

Deyrup, M. and E.S. Menges.1997. Pollination Ecology of the Rare Scrub Mint Dicerandra frutescens (Lamiaceae). Florida. Scientist 60(3):143-157.

DMP. 1970. Medicinal plants of Nepal. Bulletin of Department of Medicinal Plant. (No.3), Department of Plant Resources, Kathmandu, Nepal. 85 pp.

Jones C. E. and R.J. Little. 1983. Handbook of Experimental Pollination Biology. Scientific and Academic Editions, New York. 558 pp.

Joshi, K. K. and S. D. Joshi. 2001. Genetic heritage of medicinal and aromatic plants of Nepal Himalayas. Budddha Academic Publishers and Distributors Pvt. Ltd., Kathmandu, Nepal.

Kearns, C.A. and D.W. Inouye. 1993. Techniques for Pollination Biologists. University Press of Colorado, Niwot, Colorado 80544, U.S.A. 583 pp.

Kearns, C.A., D.W. Inouye and N.M. Waser. 1998. Endangered Mutualisms: The Conservation of PlantPollinator Interactions .Annual, Rev. Ecol. Syst. 29:88-112.

Kochhar, S.L. 1998. Economic Botany in the Tropics. Man Millan India Limited, Daryaganj, New Delhi, 604 pp.

Macior, L. W. and Y. Tang.1997. A Preliminary Study of the Pollination Ecology of Pedicularis in the Chinese Himalaya. Plant Species Biology 12:1-7. 
Subodh Adhikari \& Mahesh Kumar Adhikari/Floral Phenology

Macior, L.W. 1990. Pollination Ecology of Pedicularis punctata Decne. (Scrophulariaceae) in the Kasmir Himalaya. Plant Species Biology (Kyoto) 5:215-223

Macior, L. W. 1984. Behavioral Coadaptation of Bombus Pollinators and Pedicularis Flowers. V ${ }^{\text {eme }}$ Symposium International Sur La Pollinisation. Versailles(27-30, Septembre 1983). (Ed. INRA Publ.) ( Les Colloqus de I' INRA, n 21). Pp. 257-261.

Macior, L.W. 1971.Co-evolution of Plants and AnimalsSystematic Insights From Plant-Insect Interactions. Taxon 20(1):17-28.

Macior, L.W. 1973. Pollination Ecology-The Study of Cooperative Interactions in Evolution. In : Pollination and Dispersal. (Ed. N.B.M. Brantjes), Department of Botany Nijmegen.

Mayfield, M. M., M.W. Nickolas and V.P. Marry 2001. Exploring the 'Most Effective Pollinator Principal' with Complex Flowers: Bumblebees and Ipomopsis aggregata. Annals of Botany (London) 88(4):591-593.

Partap, U. 1997. Bee Flora of the Hindukush-Himalayas. Inventory and Management. ICIMOD. KTM. Nepal. 297 pp.
Partap, V. and T. Partap 2001. Declining Apple Production and Worried Himalayan Farmers: Promotion of Honeybees for Pollination. In : Issues in Mountain Development. (Eds. ICIMOD. Ktm). Nepal, Vol.-1.

Proctor, M., P.Yeo and A. Lack. 1996. The Insect Visitors III: Bees and Their Relatives. In : The Natural History of Pollination. Timber Press, Portland. Oregon, U.S.A.

Thomson, J. D. and G. Keren .2001. Pollen Removal and Deposition by Honeybee and Bumblebee Visitors to Apple and Almond Flowers. Journal of Applied ecology. 38(5):1032-1044.

WHO .1999. The use of Traditional Medicine in Primary Health Care. SEARO Regional Health Papers No.19, World Helath Organisation A.I.T.B.S. Publishers and Distributors, Delhi, India.

Zhong, L. A., L. Zhu, and W. Hong. 2001. Pollination Ecology of a Pioneer Species: Musa itinerans (Musaceae) in Xishuang banna, South Yunnan, China. Acta Botanica Sinica 43(3):319-322.

Internet visit: http://www.herbdatanz.com/ pomeganate.htm (Herbdata-New Zealand, compiled and edited by Ivor Hughes). 
Nepal Journal of Science and Technology 11 (2010) 115-124 